\title{
EVALUASI CADANGAN MUNGKIN UNTUK SISTEM PANAS BUMI VULKANIK DENGAN METODE VOLUMETRIK: STUDI AREA KAMOJANG DAN LAHENDONG
}

\section{EVALUATION OF GEOTHERMAL POSSIBLE RESERVES FOR VOLCANIC GEOTHERMAL SYSTEM USING VOLUMETRIC METHOD: AREA OF STUDY IN KAMOJANG AND LAHENDONG}

\author{
Lia Putriyana \\ Pusat Penelitian dan Pengembangan Teknologi Ketenagalistrikan, Energi Baru Terbarukan \\ dan Konservasi Energi, Kementerian Energi dan Sumber Daya Mineral \\ lia.putriyana@gmail.com
}

\begin{abstract}
ABSTRAK
Di Indonesia perkiraan sumber daya didasarkan pada SNI 13-6482-2000 mengenai Angka parameter dalam estimasi potensi energi panas bumi di Indonesia. Studi ini bertujuan untuk mengevaluasi cadangan mungkin panas bumi menggunakan metode Volumetric - heat stored dengan simulasi Monte Carlo untuk memperoleh probabilitas dari parameter-parameter yang memiliki tingkat ketidakpastian. Studi ini menggunakan analogi lapangan eksisting Kamojang dan Lahendong, yang berada pada jalur vulkanik yang sama dan memiliki kemiripan tatanan geologi, sehingga karakteristik reservoirnya tidak berbeda jauh. Empat parameter yang dibahas untuk mengevaluasi perhitungan cadangan mungkin adalah saturasi air, porositas batuan, recovery factor dan faktor konversi listrik. Hasil perhitungan cadangan mungkin untuk lapangan dominasi air yang diusulkan sebesar 152,73 MW, sedangkan yang menggunakan SNI 13-6482-2000 sebesar 152,07 MW. Hasil perhitungan untuk lapangan dominasi uap yang diusulkan sebesar 53,62 MW, perbedaan nilainya sangat signifikan dengan hasil perhitungan cadangan mungkin menggunakan SNI 13-6482-2000 sebesar 152,07 MW.
\end{abstract}

Kata kunci: Evaluasi cadangan mungkin, Sistem panas bumi vulkanik, Metode volumetric heat stored

\begin{abstract}
Indonesia is blessed with a huge geothermal energy potential up to $29 \mathrm{GW}$, which is distributed in 331 areas, mostly associated with volcanic environment. In Indonesia, resource estimation is based on Indonesian Nasional Standard (SNI-13-6482-2000). This study reviews the possible reserves estimation, Volumetric - heat stored is preferred method on initial stage exploration. The Volumetric - heat stored is proposed to be combined with Monte Carlo Simulation to obtain the probability distribution for several uncertain parameters. Using analogy of existing fields, Kamojang and Lahendong, represent other volcanic geothermal systems in Indonesia, due to the same volcanic path and identic geological setting, so that their reservoir characteristics are considered not so different. Four parameters have been researched are water saturation, rock porosity, recovery factor and electricity conversion factor. The result of possible reserve estimation for water dominated geothermal field based on proposed value is $152.73 \mathrm{MW}$, while based on SNI 13-6482-2000 is 152.07 MW. For vapor dominated geothermal field it is 53.62 $M W$, this result is significantly different to the estimation based on SNI 13-6482-2000 which is 152.07 MW.
\end{abstract}

Keywords: Reviews of possible reserves, Volcanic geothermal system, Volumetric -heat stored method 


\section{PENDAHULUAN}

Melalui Kebijakan Energi Nasional, pemerintah menetapkan target bauran energi primer yang akan dicapai pada tahun 2025 sebesar $23 \%$ dari total proyeksi kebutuhan energi, artinya 45.044 MW ditargetkan akan dipenuhi dari pembangkit listrik energi baru terbarukan (EBT). Terdapat kurang lebih 29 GW total potensi energi panas bumi, hingga Desember 2017 namun baru termanfaatkan sebesar 1.808,5 MW. Tabel 1 memperlihatkan sebaran potensi energi panas bumi Indonesia yang telah disesuaikan dengan SNI 6009:2017 mengenai Klasifikasi sumber daya dan cadangan energi panas bumi Indonesia (Badan Standardisasi Nasional. SNI 6009-2017).

\section{Klasifikasi Sumber Daya Panas Bumi}

Klasifikasi sumber daya dan cadangan energi panas bumi di Indonesia berdasarkan tahapan penyelidikan yang mencakup penyelidikan geologi, geokimia, geofisika, teknik reservoir, dan estimasi kesetaraaan listrik, telah disusun dalam SNI 6009:2017. Alur kegiatan penyelidikan dan pengembangan panas bumi seperti yang terlihat pada Gambar 1. Sumber daya (resource) adalah bagian dari potensi energi yang diharapkan dapat dimanfaatkan, sementara cadangan (reserve) adalah bagian dari sumber daya energi yang telah diketahui dimensi, sebaran kuantitas dan kualitasnya, yang telah dikaji dan dinyatakan layak untuk dieksplorasi. Sumber daya panas bumi dibagi dalam dua kelas yaitu kelas sumber daya spekulatif dan hipotesis. Cadangan panas bumi diketahui dari hasil penyelidikan rinci dan dibagi menjadi tiga kelas yaitu kelas mungkin, terduga, dan terbukti.

Cadangan mungkin panas bumi dihitung dengan menggunakan metode volumetrik heat stored untuk mengetahui jumlah panas yang tersimpan dalam batuan dan fluida, kemudian memperkirakan seberapa besar panas yang dapat dimanfaatkan untuk membangkitkan listrik. Metode volumetrik - heat stored digunakan untuk memperkirakan potensi panas bumi pada saat belum tersedianya data pemboran sumur. Seiring dengan berjalannya tahapan proses pengusahaan panas bumi, penambahan data akan meningkatkan kepastian potensi panas bumi dan metode yang digunakan bukan lagi metode volumetrik - heat stored melainkan model numerik karena tingkat akurasinya lebih baik. Metode volumetrik - heat stored memiliki kelemahan karena tingkat kepastian yang rendah, seringkali perkiraan potensi panas bumi terlalu besar dikarenakan banyaknya parameter yang diasumsikan. Hasil perkiraan potensi panas bumi akan dijadikan acuan dalam penyusunan Kebijakan Energi Nasional (KEN), oleh karena itu tingkat nilai potensi energi panas bumi setidaknya dapat mewakili kondisi sebenarnya, dalam artian lebih rasional dengan kondisi teknologi dan ekonomi saat ini. Studi ini dilakukan untuk meningkatkan validitas estimasi potensi energi panas bumi, berdasarkan hipotesa awal kelemahan metode dan angka parameter untuk perhitungan sumber daya panas bumi di Indonesia yang terdapat dalam SNI13-6482-2000 mengenai Angka Parameter Dalam Estimasi Potensi Energi Panas Bumi yang memiliki kelemahan dalam pengasumsian angka parameter yang digunakan

Tabel 1. Sebaran potensi energi panas bumi per Desember 2017

\begin{tabular}{|c|c|c|c|c|c|c|c|c|}
\hline \multirow{2}{*}{ No. } & \multirow{2}{*}{ Pulau } & \multirow{2}{*}{$\begin{array}{l}\text { Jumlah } \\
\text { Lokasi }\end{array}$} & \multicolumn{2}{|c|}{ Sumber Daya, MWe } & \multicolumn{3}{|c|}{ Cadangan, MWe } & \multirow{2}{*}{$\begin{array}{c}\text { Terpasang, } \\
\text { MWe }\end{array}$} \\
\hline & & & Spekulatif & Hipotetis & Mungkin & Terduga & Terbukti & \\
\hline 1 & Sumatera & 98 & 2817 & 1917 & 5065 & 930 & 917 & 452 \\
\hline 2 & Jawa & 73 & 1410 & 1689 & 3949 & 1373 & 1865 & 1224 \\
\hline 3 & Bali & 6 & 70 & 22 & 122 & 110 & 30 & 0 \\
\hline 4 & $\begin{array}{l}\text { Nusa } \\
\text { Tenggara }\end{array}$ & 28 & 225 & 395 & 901 & 0 & 15 & 12,5 \\
\hline
\end{tabular}




\section{MAKALAH ILMIAH}

\begin{tabular}{|c|c|c|c|c|c|c|c|c|}
\hline \multirow{2}{*}{ No. } & \multirow{2}{*}{ Pulau } & \multirow{2}{*}{$\begin{array}{l}\text { Jumlah } \\
\text { Lokasi }\end{array}$} & \multicolumn{2}{|c|}{ Sumber Daya, MWe } & \multicolumn{3}{|c|}{ Cadangan, MWe } & \multirow{2}{*}{$\begin{array}{c}\text { Terpasang, } \\
\text { MWe }\end{array}$} \\
\hline & & & Spekulatif & Hipotetis & Mungkin & Terduga & Terbukti & \\
\hline 5 & Kalimantan & 14 & 152 & 17 & 13 & 0 & 0 & 0 \\
\hline 6 & Sulawesi & 87 & 1308 & 325 & 1248 & 80 & 140 & 120 \\
\hline 7 & Maluku & 33 & 560 & 91 & 677 & 0 & 0 & 0 \\
\hline 8 & Papua & 3 & 75 & 0 & 0 & 0 & 0 & 0 \\
\hline \multirow{2}{*}{\multicolumn{2}{|c|}{ Total }} & 342 & 6617 & 4456 & 11975 & 2493 & 2967 & \multirow{2}{*}{1808,5} \\
\hline & & & \multicolumn{2}{|c|}{11073} & & 17435 & & \\
\hline
\end{tabular}

Sumber : Peta Distribusi Daerah dan Potensi Panas Bumi Indonesia. Badan Geologi Kementerian ESDM

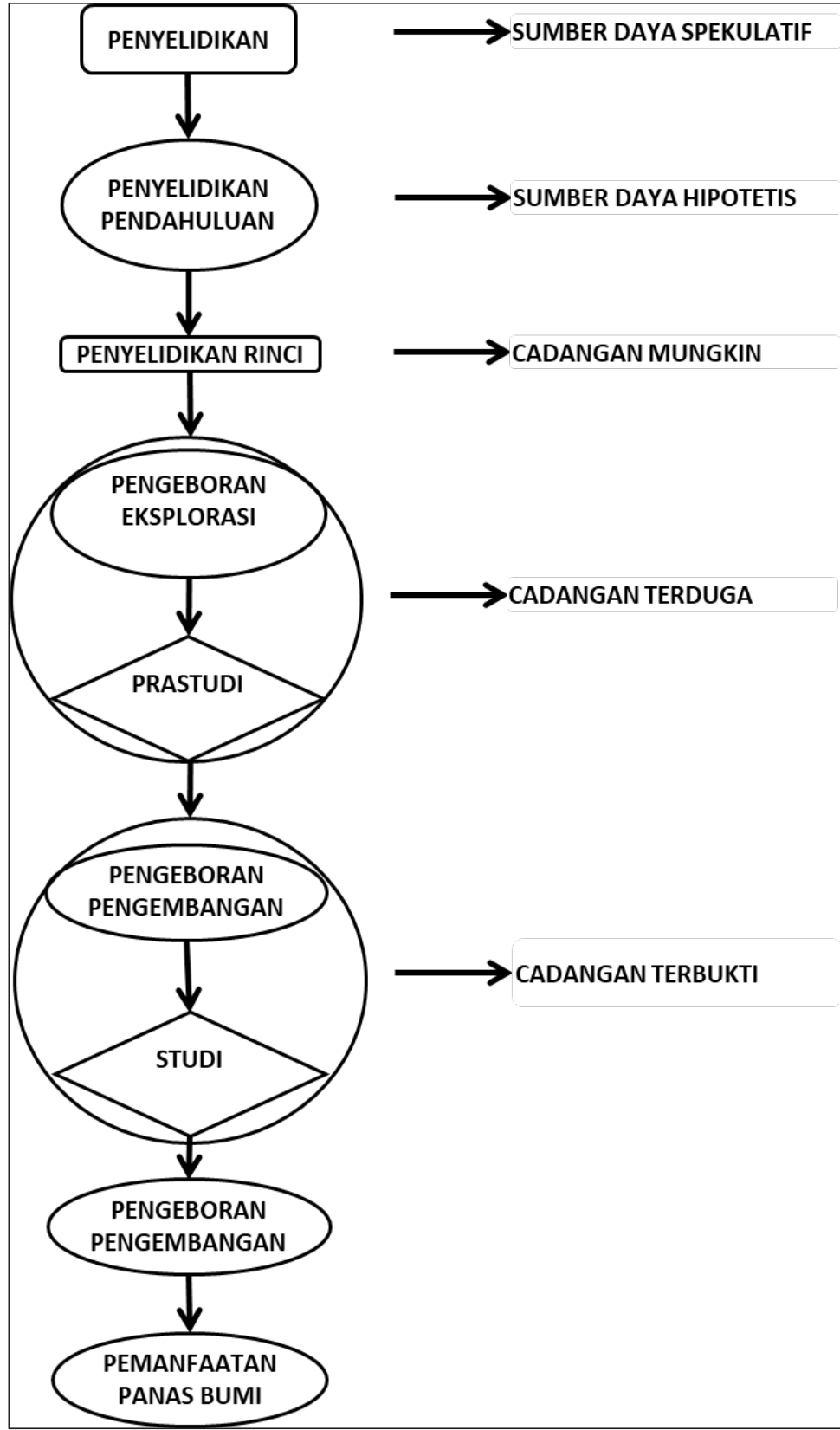

Gambar 1. Alur kegiatan penyelidikan dan pengembangan panas bumi, telah disesuaikan dengan SNI 6009:2017 


\section{METODE}

Studi ini bersifat desk study mengenai evaluasi perhitungan cadangan mungkin panas bumi di Indonesia dibatasi pada sistem panas bumi vulkanik mengingat 12 lapangan panas bumi yang sudah dikembangkan keseluruhannya merupakan sistem panas bumi vulkanik. Evaluasi hanya dilakukan pada nilai cadangan mungkin panas bumi hasil perhitungan dengan acuan SNI 13-64822000 mengenai Angka Parameter Dalam Estimasi Potensi Energi Panas Bumi (Badan Standardisasi Nasional. SNI 136482-2000). Perkiraan cadangan mungkin panas bumi dilakukan dengan menggunakan asumsi beberapa nilai parameter mengingat keterbatasan data pada tahap awal penyelidikan pendahuluan dan penyelidikan pendahuluan lanjutan. Nilai parameter yang digunakan pada SNI 13-6482-2000 dievaluasi dengan cara membandingkan dengan nilai parameter pada lapangan panas bumi yang sudah dikembangkan, sehingga diharapkan dapat diperoleh nilai yang lebih rasional untuk menghitung cadangan mungkin panas bumi dan dapat menghindari over estimation.

Evaluasi cadangan mungkin panas bumi dilakukan dengan mencari lapangan pembanding yang sesuai dengan kondisi lapangan panas bumi di Indonesia pada umumnya. Lapangan panas bumi Kamojang yang merupakan sistem panas bumi vulkanik dominasi uap dan Lahendong yang merupakan sistem panas bumi dominasi air, akan dijadikan studi area. Pemilihan dua lapangan tersebut dapat mewakili kondisi lapangan panas bumi system vulkanik lainnya yang berada di Indonesia karena berada pada jalur vulkanik yang sama dan memiliki kemiripan tatanan geologi, sehingga karakteristik reservoirnya tidak berbeda jauh.

Metode volumetrik - heat stored banyak digunakan oleh industri panas bumi. Metode volumetrik - heat stored merupakan metode yang konsisten untuk diaplikasikan dalam perhitungan cadangan pada tahap awal eksplorasi (Sarmiento, Z.F. and G. Björnsson., 2007). Metode ini pertama kali diperkenalkan oleh United State of Geological Survey, dalam perkembangannya mengalami beberapa penyesuaian sesuai dengan perkembangan teknologi dan ekonomi. Metode volumetrik - heat stored menghitung energi panas yang tersimpan pada batuan dan fluida reservoir baik berupa air maupun uap, total dari energi panas tersebut kemudian dihitung konversi menjadi energi listrik.

Berdasarkan SNI 13-6482-2000 mengenai Angka parameter dalam estimasi potensi energi panas bumi, energi panas yang tersimpan dalam batuan dihitung dengan persamaan berikut:

$Q_{r}=A \cdot h \cdot(1-\varphi) \cdot \rho_{r} \cdot c_{r}$

(1)

Dimana:

$Q_{r} \quad$ : energi panas dalam batuan, $\mathrm{kJ}$

A : luas area prospek, $\mathrm{m}^{2}$

h : ketebalan, $\mathrm{m}$

$\varphi \quad$ : porositas, $\%$

$\rho_{r} \quad$ : densitas batuan, $\mathrm{kg} / \mathrm{m}^{3}$

$\mathrm{C}_{\mathrm{r}} \quad$ : kapasitas panas batuan, $\mathrm{kJ} / \mathrm{kg} .{ }^{\circ} \mathrm{C}$

Energi panas yang tersimpan dalam fluida reservoir dapat berupa air atau uap, atau campuran keduanya. Jumlah air atau uap yang terkandung dalam reservoir digambarkan sebagai nilai saturasi uap $\left(S_{v}\right)$ atau saturasi air $\left(S_{w}\right)$. Energi panas air yang terkandung dalam reservoir dihitung dengan persamaan berikut:

$Q_{W}=A \cdot h \cdot \varphi \cdot \rho_{W} \cdot S_{W} \cdot\left(h_{W i}-h_{w f}\right)$

Dimana:

$Q_{w} \quad$ : energi panas dalam fluida, $\mathrm{kJ}$

$\rho_{\mathrm{w}} \quad$ : densitas air, $\mathrm{kg} / \mathrm{m}^{3}$

$h_{W i} \quad$ : enthalpy fluida initial, $\mathrm{kJ} / \mathrm{kg}$

$h_{w f} \quad$ : enthalpy fluida final, $\mathrm{kJ} / \mathrm{kg}$

Sedangkan persamaan untuk menghitung energi panas uap yang terkandung dalam reservoir adalah: 
$Q_{V}=A \cdot h \cdot \varphi \cdot \rho_{V} \cdot\left(1-S_{W}\right) \cdot\left(h_{W i}-h_{w f}\right)$

(3)

Dimana:

$Q_{v} \quad$ : energi panas dalam uap, $\mathrm{kJ}$

$\rho_{\mathrm{v}} \quad$ : densitas uap, $\mathrm{kg} / \mathrm{m}^{3}$

Sehingga total energi panas yang terkandung pada reservoir adalah:

$Q_{t}=Q_{r}+Q_{W}+Q_{V}$

Energi listrik dihitung dengan mengkonversi total energi panas yang terkandung dalam reservoir $\left(Q_{t}\right)$

$Q_{e}=\frac{Q_{t} \cdot R_{f} \cdot C_{e}}{\eta \cdot 365.24 .3600 .1000}$

Dimana:

$\mathrm{R}_{\mathrm{f}} \quad$ : recovery factor, $\%$

$c_{e} \quad$ : faktor konversi, $\%$

Studi ini membahas mengenai sistem panas bumi vulkanik yang memiliki karakteristik temperatur tinggi, sehingga nilai parameter pada SNI 13-6482-2000 yang akan dibahas yaitu nilai parameter untuk perhitungan cadangan mungkin pada lapangan bertemperatur tinggi $\left(>225^{\circ} \mathrm{C}\right)$ seperti yang ditunjukan pada Tabel 2 .

Tabel 2. Nilai parameter untuk perhitungan cadangan mungkin energi panas bumi

\begin{tabular}{ll}
\hline Parameter & Nilai \\
\hline Saturasi air (\%) & 100 \\
\hline Porositas batuan (\%) & 10 \\
\hline $\begin{array}{l}\text { Kapasitas panas batuan, } \\
\mathrm{kJ} / \mathrm{kg} .{ }^{\circ} \mathrm{C}\end{array}$ & 1 \\
\hline Densitas batuan, $\mathrm{kg} / \mathrm{m}^{3}$ & $2,5 \times 10^{3}$ \\
\hline Umur pembangkitan (tahun) & 30 \\
\hline Faktor konversi, \% & 10 \\
\hline Sumber (SNI 13-6482-2000)
\end{tabular}

Angka-angka parameter pada kelas cadangan mungkin ini ditentukan dengan pertimbangan sebagai berikut:

1) Saturasi air $100 \%$ karena fluida dalam reservoar dianggap jenuh air, dengan anggapan bahwa lapangan panas bumi tersebut adalah dominasi air.

2) Porositas batuan didasarkan kepada hasil rata-rata pengukuran porositas batuan vulkanik di beberapa lapangan panas bumi.
3) Kapasitas panas batuan ditentukan berdasarkan asumsi.

4) Densitas batuan ditentukan berdasarkan hasil pengukuran dari batuan ubahan di lapangan panas bumi.

5) Umur pembangkitan listrik ditentukan berdasarkan pada lama waktu (umur) pembangkitan listrik.

6) Faktor konversi listrik ditentukan berdasarkan kemungkinan kehilangan energi panas setelah ditransfer ke dalam energi listrik.

Nilai recovery factor dihitung dengan menggunakan persamaan:

$R_{f}=\frac{T_{i}-T_{f}}{T_{i}-T_{S}} x 100$

Dimana:

$\mathrm{T}_{\mathrm{i}} \quad$ : Temperatur awal, ${ }^{\circ} \mathrm{C}$

$\mathrm{T}_{\mathrm{f}} \quad:$ Temperatur akhir, ${ }^{\circ} \mathrm{C}$

$\mathrm{T}_{\mathrm{s}} \quad$ : Temperatur permukaan, ${ }^{\circ} \mathrm{C}$

\section{HASIL DAN PEMBAHASAN}

Beberapa parameter yang digunakan dalam memperkirakan cadangan mungkin panas bumi memiliki tingkat ketidakpastian yang sangat tinggi seringkali menyebabkan estimasi cadangan mungkin yang berlebih. Beberapa parameter tersebut antara lain;

1. Saturasi air

2. Porositas batuan

3. Recovery factor

4. Faktor konversi listrik

\section{Saturasi air}

Fluida reservoir pada lapangan dominasi uap Kamojang memiliki saturasi air sebesar $25-30 \%$ yang dibuktikan dari jumlah air yang keluar dari sumur produksi dengan demikian nilai saturasi uap sebesar $70-75 \%$ (Utami, P., 2000). Pada lapangan panas bumi dominasi air berlaku sebaliknya, nilai saturasi air yang terkandung dalam reservoir sebanyak $70 \%$ dengan jumlah uap sebanyak $30 \%$.

\section{Porositas batuan}

Nilai porositas menggambarkan kemampuan batuan untuk menyimpan fluida, porositas dapat terukur dengan data 


\section{MAKALAH ILMIAH}

core hasil pemboran. Pada tahap penyelidikan rinci belum terdapat sumur pemboran sehingga nilai porositas merupakan nilai yang diasumsikan, namun asumsi yang digunakan harus memiliki dasar yang kuat. Pada studi ini nilai porositas diwakili dari dua lapangan panas bumi dengan sistem vulkanik, yang mewakili kondisi sistem panas bumi di Indonesia pada umumnya. Lapangan Kamojang merupakan sistem panas bumi vulkanik dominasi uap. Porositas reservoir yang terdiri dari batuan basaltic andesite berkisar 4-7\% (Sudarman, dkk., 1995). Lapangan Lahendong merupakan sistem panas bumi vulkanik dominasi air. Porositas reservoir yang terdiri dari beberapa formasi batuan berkisar 10-22\% (Yani, A., 2006).

\section{Recovery factor}

Nilai recovery factor menggambarkan seberapa besar energi yang dapat diambil dari reservoir panas bumi. Nilai tersebut memiliki korelasi terhadap permeabilitas dan porositas reservoir, dengan sistem panas bumi yang yang berbeda akan memiliki nilai recovery factor yang berbeda (L.J.P. Muffler). Nilai recovery factor diketahui dengan memplotkan nilai porositas terhadap garis korelasi seperti yang terlihat pada Gambar 2.
Lapangan panas bumi dominasi uap dengan nilai porositas berkisar 4-7\% memiliki nilai recovery factor antara 10$17,5 \%$, sedangkan untuk lapangan panas bumi dominasi air dengan porositas berkisar $10-22 \%$ memiliki nilai recovery factor antara $25-50 \%$. Semakin besar nilai recovery factor yang digunakan akan berpengaruh pada jumlah potensi panas bumi hasil perhitungan.

\section{Faktor Konversi Listrik}

Secara keseluruhan faktor konversi listrik dipengaruhi oleh beberapa parameter antara lain desain pembangkit, kandungan Non Condensible Gas (NCG), kondisi ambient, dan lain-lain (Moon, $\mathrm{H}$., dan Zarrouk, S.J., 2012). Secara umum jenis pembangkit yang digunakan pada sistem panas bumi vulkanik dominasi uap adalah single flash, sedangkan dominasi air menggunakan jenis pembangkit double flash. Gambar 3 dan Gambar 4 menunjukan nilai faktor konversi listrik berdasarkan jenis pembangkit dan temperatur fluida reservoir, selama ini SNI 13-6482-2000 mengenai Angka parameter dalam estimasi potensi energi panas bumi menyatakan nilai faktor konversi listrik sebesar $10 \%$ tanpa mempertimbangkan jenis pembangkit yang digunakan.

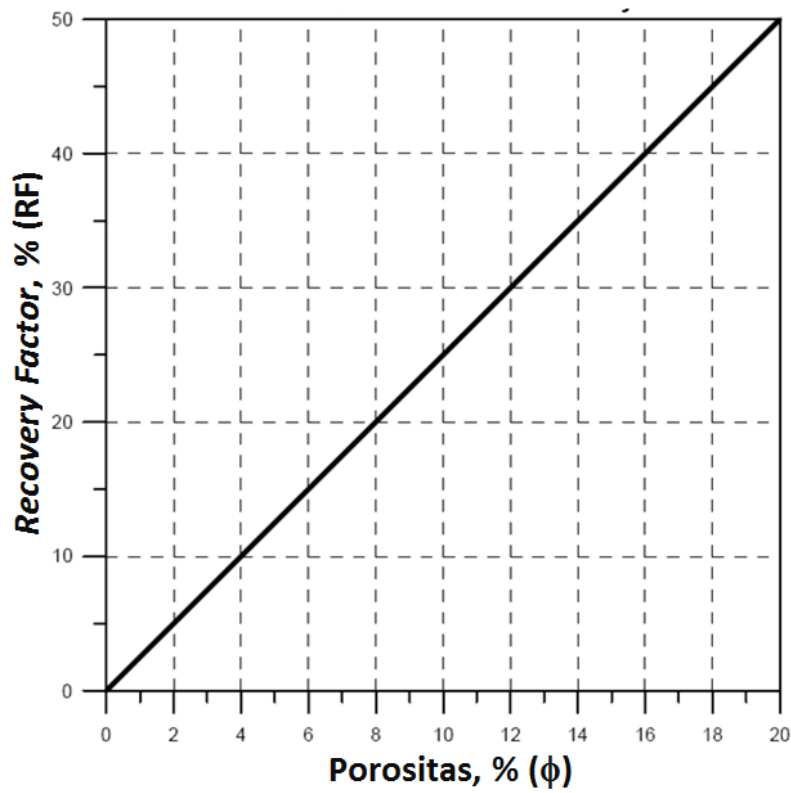

Gambar 2. Korelasi nilai recovery factor teoritis dan porositas Sumber (Muffler, 1978) 
Gambar 3 menunjukan korelasi enthalpy fluida reservoir dengan faktor konversi listrik untuk pembangkit Single Flash dan Dry Steam yang sesuai digunakan untuk lapangan panas bumi dominasi uap. Enthalpy fluida reservoir pada tahap penyelidikan rinci diketahui dari hasil perhitungan Geothermometer untuk memperkirakan temperatur fluida reservoir.
Gambar 4 menunjukan korelasi enthalpy fluida reservoir dengan faktor konversi listrik untuk pembangkit tipe Double Flash yang sesuai digunakan pada lapangan panas bumi dominasi air. Enthalpy fluida reservoir pada tahap penyelidikan rinci diketahui dari hasil perhitungan Geothermometer untuk memperkirakan temperatur fluida reservoir.

- Efisiensi Aktual (data tidak digunakan)

Efisiensi Aktual (data digunakan)

- Efisiensi Aktual

— Efisiensi Turbin Uap (AGEA, 2010)

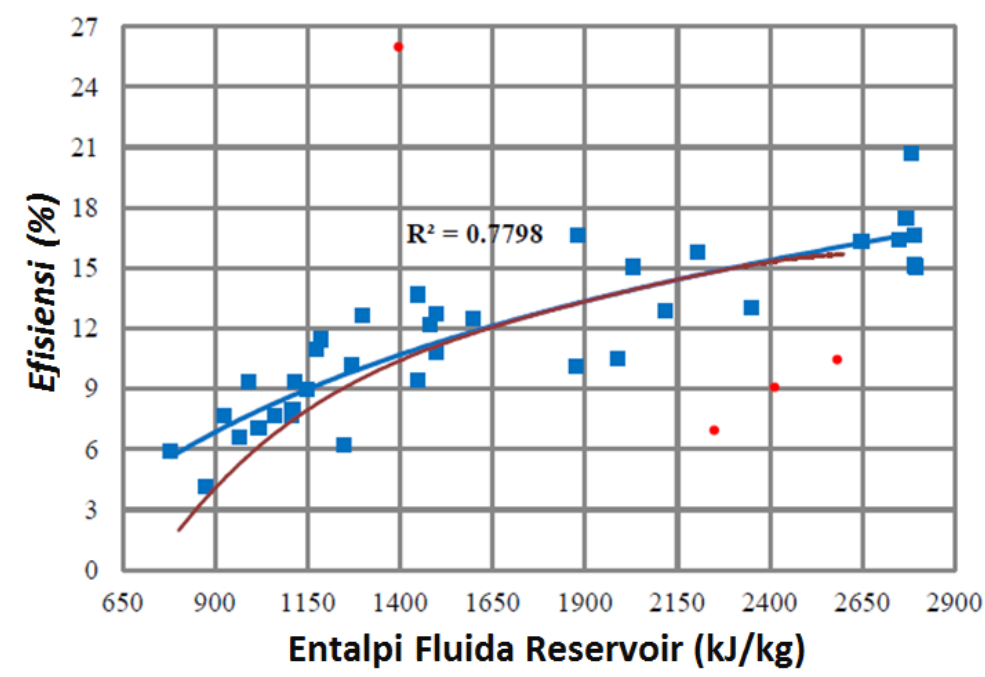

Gambar 3. Korelasi enthalpy reservoir dengan efisiensi (faktor konversi listrik) untuk tipe Single Flash dan Dry Steam. Sumber (Moon, H., and Zarrouk, S.J., 2012)

- Efisiensi Aktual (data tidak digunakan)

Efisiensi Aktual (data digunakan)

- Efisiensi Aktual

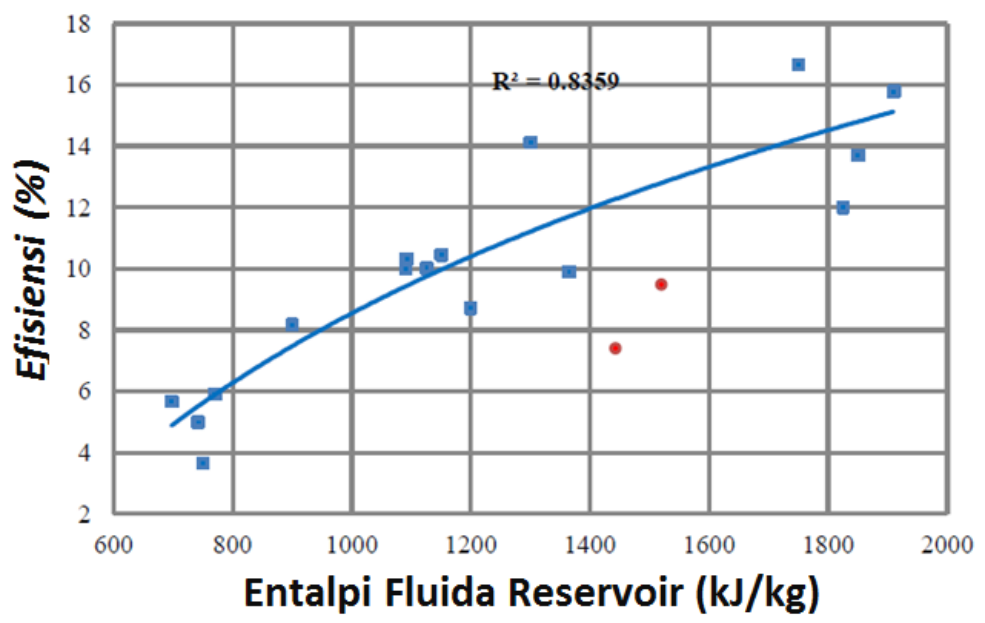

Gambar 4. Korelasi enthalpy reservoir dan efisiensi (faktor konversi listrik) untuk tipe Double Flash. Sumber (Moon, H., and Zarrouk, S.J., 2012) 
Tabel 3. Perbandingan nilai parameter untuk perhitungan cadangan mungkin energi panas bumi

\begin{tabular}{lccc}
\hline \multirow{1}{*}{ Parameter } & SNI & \multicolumn{2}{c}{ Usulan } \\
\cline { 2 - 4 } & & $\begin{array}{c}\text { Dom. } \\
\text { Uap }\end{array}$ & $\begin{array}{c}\text { Dom. } \\
\text { Air }\end{array}$ \\
\hline Saturasi air, \% & 100 & 30 & 70 \\
\hline $\begin{array}{l}\text { Porositas batuan, } \\
\%\end{array}$ & 10 & $4-7$ & $10-22$ \\
\hline $\begin{array}{l}\text { Recovery factor, } \\
\%\end{array}$ & 50 & $10-17,5$ & $25-50$ \\
\hline $\begin{array}{l}\text { Faktor konversi, } \\
\%\end{array}$ & 10 & $15-18$ & $10-12$ \\
\hline
\end{tabular}

Berdasarkan pembahasan sebelumnya mengenai parameter saturasi air dan uap, porositas batuan, recovery factor dan faktor konversi listrik, maka diusulkan nilai parameter-parameter seperti yang ditunjukkan pada Tabel 3.

Untuk menghitung cadangan mungkin panas bumi dengan metode volumetrik dimana terdapat beberapa parameter dengan rentang nilai tertentu digunakan simulasi Monte Carlo yaitu metode statistik probabilistik untuk menghitung beberapa parameter yang memiliki nilai minimum, most likely dan maksimum (Geyer, C.J., 2010). Perhitungan ini dilakukan secara berulang-ulang (iterasi) untuk mendapatkan fungsi probabilitas dan fungsi distribusi parameter. Langkahlangkah simulasi Monte Carlo sebagai berikut:

1. Menetapkan distribusi probabilitas untuk variabel-variabel utama

2. Menetapkan distribusi kumulatif untuk setiap variabel

3. Menentukan interval dari bilanganbilangan acak untuk setiap variabel

4. Membuat bilangan random

5. Menjalankan simulasi dari rangkaian percobaan

Fungsi distribusi yang digunakan dalam simulasi Monte Carlo disesuaikan dengan nilai parameter yang disebutkan pada Tabel 3. Nilai parameter yang memiliki rentang minimum, most likely dan maksimum menggunakan fungsi distribusi segitiga, sedangkan nilai parameter yang hanya memiliki rentang minimum dan maksimum menggunakan fungsi distribusi segiempat. Beberapa parameter berikut nilainya diasumsikan yaitu:

Luas area prospek, $\mathrm{A}$ : 10,15 dan 20

$\mathrm{km}^{2}$

Ketebalan reservoir, $\mathrm{h} \quad: 500,750,1000$ $\mathrm{m}$

Densitas batuan, $\rho_{\mathrm{r}} \quad: 2.700 \mathrm{~kg} / \mathrm{m}^{3}$

Kapasitas panas batuan, $\mathrm{c}_{\mathrm{r}}: 1 \mathrm{~kJ} / \mathrm{kg} .{ }^{\circ} \mathrm{C}$

Untuk lapangan dominasi air

Saturasi air, $S_{w}$

Saturasi uap, $\mathrm{S}_{\mathrm{v}}$

Temperatur awal, $T_{i}$

$: 70 \mathrm{~kg} / \mathrm{m}^{3}$

$: 30 \mathrm{~kg} / \mathrm{m}^{3}$

Temperatur akhir, $T_{f}$

: $250^{\circ} \mathrm{C}$

$: 180^{\circ} \mathrm{C}$

Untuk lapangan dominasi uap

Saturasi air, $S_{w}$

Saturasi uap, $\mathrm{S}_{\mathrm{v}}$

Temperatur awal, $T_{i}$

$: 30 \mathrm{~kg} / \mathrm{m}^{3}$

$: 70 \mathrm{~kg} / \mathrm{m}^{3}$

Temperatur akhir, $T_{f}$

: $240^{\circ} \mathrm{C}$

: $180^{\circ} \mathrm{C}$

Fungsi distribusi yang digunakan dalam simulasi Monte Carlo disesuaikan dengan nilai parameter yang disebutkan pada Tabel 3. Nilai parameter yang memiliki rentang minimum, most likely dan maksimum menggunakan fungsi distribusi segitiga, sedangkan nilai parameter yang hanya memiliki rentang minimum dan maksimum menggunakan fungsi distribusi segiempat.

Area prospek dan ketebalan reservoir yang diperoleh langsung dari hasil pengukuran menggunakan distribusi segitiga. Sedangkan nilai porositas, recovery factor 


\section{MAKALAH ILMIAH}

dan faktor konversi listrik yang hanya memiliki rentang nilai minimum dan maksimum menggunakan fungsi distribusi segiempat. Berikut merupakan hasil perhitungan menggunakan simulasi Monte Carlo dengan menggunakan angka parameter SNI dan usulan seperti yang tertera pada (Tabel 3).

Tabel 4. Perhitungan menggunakan angka parameter SNI 13-6482-2000

\begin{tabular}{|c|c|c|c|c|c|}
\hline & Min & Max & Most & & \\
\hline Area $(\mathrm{sq}-\mathrm{km})=$ & 10 & 20 & 15 & & \\
\hline Thickness $(\mathrm{m})=$ & 500 & 1000 & 750 & $P 10=$ & $83,84 \mathrm{MW}$ \\
\hline Rock Dens. $(\mathrm{kg} / \mathrm{cu}-\mathrm{m})=$ & 2500 & & & $P 50=$ & $114,82 \mathrm{MW}$ \\
\hline Porosity (fract) $=$ & $10 \%$ & & & $P 90=$ & $152,07 \mathrm{MW}$ \\
\hline Rock Heat Cap. $(\mathrm{kJ} /(\mathrm{kg} \cdot \operatorname{deg}-\mathrm{C}))=$ & 1 & & & & \\
\hline Life Time $($ years) $=$ & 30 & & & & \\
\hline $\operatorname{RF}($ fract $)=$ & 0,5 & & & & \\
\hline Elect. Eff. (fract) $=$ & 0,1 & & & & \\
\hline $\mathrm{Ti}($ deg $-\mathrm{C})=$ & 250 & & & & \\
\hline $\operatorname{Tf}(\operatorname{deg}-\mathrm{C})=$ & 180 & & & & \\
\hline Water Sat. Init. (fract) $=$ & $100 \%$ & & & & \\
\hline Water Sat. Fina. (fract) $=$ & $10 \%$ & & & & \\
\hline
\end{tabular}

Tabel 5. Perhitungan menggunakan angka parameter usulan untuk lapangan dominasi air

\begin{tabular}{|c|c|c|c|c|c|}
\hline & Min & Max & Most & & \\
\hline Area $(\mathrm{sq}-\mathrm{km})=$ & 10 & 20 & 15 & & \\
\hline Thickness $(\mathrm{m})=$ & 500 & 1000 & 750 & $\mathrm{P} 10=$ & $67,77 \mathrm{MW}$ \\
\hline Rock Dens. $(\mathrm{kg} / \mathrm{cu}-\mathrm{m})=$ & 2500 & & & $P 50=$ & $104,39 \mathrm{MW}$ \\
\hline Porosity $($ fract $)=$ & $10 \%$ & $22 \%$ & & $P 90=$ & $152,73 \mathrm{MW}$ \\
\hline Rock Heat Cap. $(\mathrm{kJ} /(\mathrm{kg} \cdot \operatorname{deg}-\mathrm{C}))=$ & 1 & & & & \\
\hline Life Time (years) $=$ & 30 & & & & \\
\hline$R F($ fract $)=$ & 0,25 & 0,5 & & & \\
\hline Elect. Eff. (fract) $=$ & 0,1 & 0,12 & & & \\
\hline $\mathrm{Ti}(\operatorname{deg}-\mathrm{C})=$ & 250 & & & & \\
\hline $\operatorname{Tf}(\operatorname{deg}-\mathrm{C})=$ & 180 & & & & \\
\hline Water Sat. Init. (fract) $=$ & $70 \%$ & & & & \\
\hline Water Sat. Fina. (fract) $=$ & $10 \%$ & & & & \\
\hline
\end{tabular}

Tabel 6.Perhitungan menggunakan angka parameter usulan untuk lapangan dominasi uap

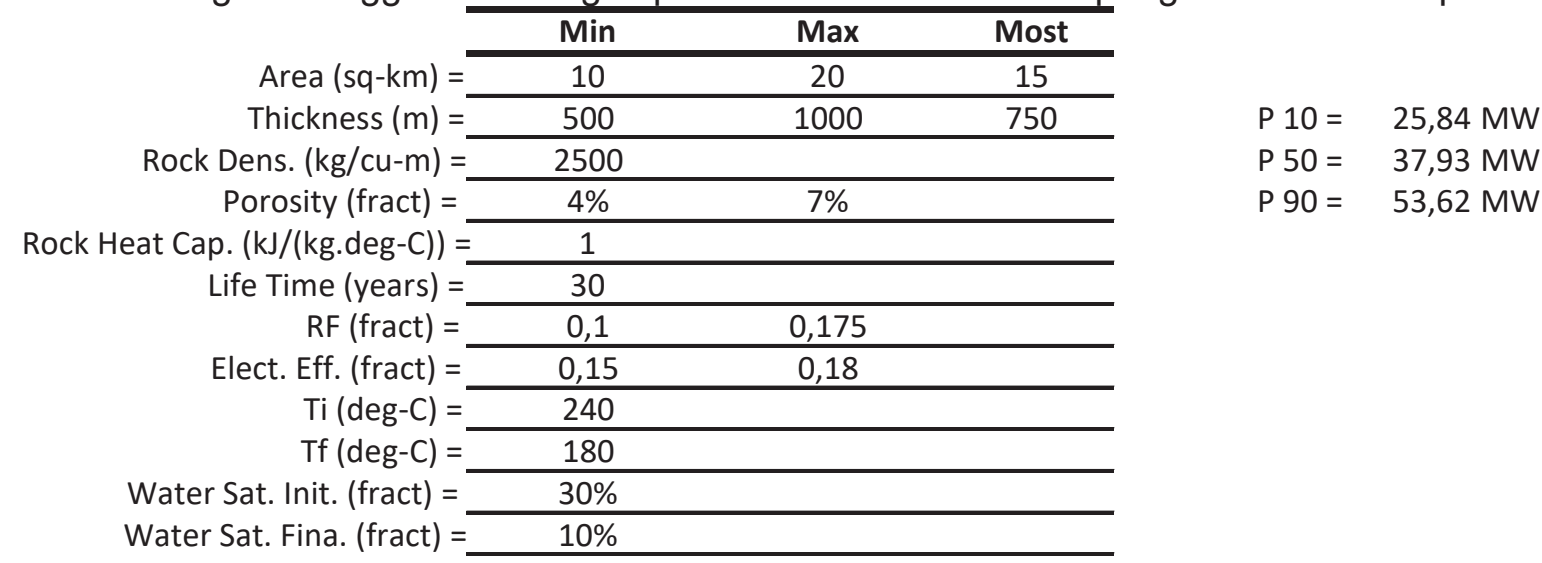




\section{HASIL DAN PEMBAHASAN}

Simulasi Monte Carlo dengan menggunakan angka parameter yang tertera pada SNI 13-6482-2000 menghasilkan perkiraan cadangan mungkin pada tingkat probabilitas 90 sebesar 152,07 MW seperti yang terlihat pada Tabel 4. Simulasi Monte Carlo dengan menggunakan angka parameter usulan untuk lapangan panas bumi dominasi air sesuai dengan referensi yang dapat mewakili kondisi sistem panas bumi vulkanik tipe dominasi air yang ada di Indonesia, didapatkan perkiraan cadangan mungkin hasil perhitungan pada tingkat probabilitas 90 sebesar 152,73 MW seperti yang terlihat pada Tabel 5. Sedangkan untuk lapangan panas bumi dominasi uap sesuai dengan referensi yang dapat mewakili kondisi sistem panas bumi vulkanik tipe dominasi uap yang ada di Indonesia, perkiraan cadangan mungkin hasil perhitungan pada tingkat probabilitas 90 sebesar 53,62 MW seperti yang terlihat pada Tabel 6 .

Terlihat perbedaan yang sangat signifikan antara hasil perhitungan dengan menggunakan angka acuan pada SNI 136482-2000 dengan hasil perhitungan cadangan mungkin untuk lapangan panas bumi dominasi uap, hal ini dikarenakan nilai porositas dan recovery factor pada lapangan panas bumi dominasi uap sangat kecil. Hal ini perlu untuk dipertimbangkan dalam perhitungan cadangan mungkin panas bumi, mengingat keterbatasan data pada tahap survei pendahuluan, untuk menghindari over estimation nilai cadangan mungkin yang didapatkan.

Untuk memudahkan dalam membedakan tipe lapangan panas bumi pada tahap studi pendahuluan dilakukan dengan mengamati manifestasi yang ada pada suatu lapangan. Untuk lapangan dominasi air, manifestasi permukaan yang umumnya ditermukan berupa mata air panas dengan debit yang relatif besar, sedangkan untuk lapangan dominasi uap, manifestasi permukaan yang umumnya ditemukan berupa fumarola, solfatara dan / atau mud pool (kolam lumpur). Hal ini dilakukan guna menghindari over estimation dalam perkiraan cadangan mungkin panas bumi.

\section{KESIMPULAN}

Hasil perhitungan cadangan mungkin dengan angka parameter usulan untuk lapangan dominasi air sebesar 152,73 MW, nilai ini tidak jauh berbeda dengan hasil perhitungan cadangan mungkin SNI 136482-2000 sebesar 152,07 MW yang selama ini digunakan sebagai acuan penyusunan kebijakan. Sedangkan hasil perhitungan cadangan mungkin dengan angka parameter usulan untuk lapangan dominasi uap sebesar 53,62 MW, perbedaan nilainya sangat signifikan dengan hasil perhitungan cadangan mungkin SNI 13-6482-2000 sebesar 152,07 MW yang selama ini digunakan sebagai acuan penyusunan kebijakan.

\section{SARAN/REKOMENDASI}

Revisi terhadap acuan angka parameter dalam estimasi potensi panas bumi yang tercantum di SNI 13-6482-2000 perlu dilakukan berdasarkan hasil pada karya tulis ilmiah ini untuk menghindari perkiraan berlebih yang dapat berpengaruh terhadap Kebijakan Energi Nasional terutama penetapan target pemanfaatan energi panas bumi dalam bauran energi.

\section{UCAPAN TERIMA KASIH}

Ucapan terima kasih penulis sampaikan untuk Badan Geologi dan Direktorat Jenderal Energi Baru Terbarukan, Kementerian Energi dan Sumber Daya Mineral atas data-data yang sudah dipublikasikan.

\section{DAFTAR ACUAN}

Badan Standardisasi Nasional. SNI 60092017: Klasifikasi Potensi Energi Panas Bumi di Indonesia. Indonesia, 2017.

Badan Geologi Kementerian ESDM. Data Sebaran Potensi Panas Bumi di Indonesia, Indonesia, 2017. 


\section{MAKALAH ILMIAH}

Badan Standarisasi Nasional. SNI 135012-1998: Klasifikasi Potensi Energi Panas Bumi di Indonesia. Indonesia, 1999.

Badan Standardisasi Nasional. SNI 136482-2000: Angka Parameter dalam Estimasi Potensi Energi Panas Bumi, 2000.

Sarmiento, Z.F. and, and G. Björnsson., 2007. "Geothermal Resources Assessment -Volumetric Reserves Estimation and Numerical Modelling." El Salvador.

L.J.P. Muffler. "Assessment of Geothermal Resources of the United States1978". Geological Survey Circular 790. U.S. Geological Survey.

Utami, P., 2000. "Characteristcs of The Kamojang Geothermal Reservoir (West Java) as Revealed by Its Hydrothermal Alteration Mineralogy". In Proceedings of World Geothermal Congress, Kyushu - Tohoku, Japan, May 28- June 10, 2000. pp. 1921 1926.
Sudarman, dkk., 1995. "Kamojang Geothermal Field 10 Year Operation Experience". In Proceedengs of World Geothermal Congress, Florence.

Yani, A., 2006. "Numerical Modelling of Lahendong Geothermal System, Indonesia". Geothermal Training Programme, number 24, page 547580. Reykjavik, Iceland.

Moon, H., dan Zarrouk, S.J., 2012. "Efficiency of Geothermal Power Plants: A Worldwide Review". In Proceedings of New Zealand Geothermal Workshop 19 - 21 November 2012. New Zealand.

Geyer, C.J., 2010. "Computation for the Introduction to MCMC chapter of Handbook of Markov Chain Monte Carlo". Technical Report 679, School of Statistics, University of Minnesota.

\begin{tabular}{|ll|}
\hline Diterima & $:$ 30 Agustus 2018 \\
Direvisi & $: 9$ Oktober 2018 \\
Disetujui & $:$ 30 November 2018
\end{tabular}

